\title{
Challenges in diagnosing ceruminous adenocarcinoma
}

\author{
Edgardo Abelardo (i) , ${ }^{1,2}$ Selwyn $\mathrm{Ng}_{1}{ }^{3}$ Laysan Pope, ${ }^{4}$ Vinod Prabhu ${ }^{1}$
}

${ }^{1}$ ENT-HNS, Hywel Dda University Health Board, Carmarthen, UK ${ }^{2}$ Institute of Life Sciences 2, Swansea University Medical School, Swansea, UK ${ }^{3}$ Pathology, Swansea Bay University Health Board, Swansea, UK

${ }^{4}$ ENT-HNS, Swansea Bay University Health Board, Swansea, UK

Correspondence to Edgardo Abelardo; E.Abelardo@swansea.ac.uk

Accepted 2 April 2021

\section{DESCRIPTION}

A 65-year-old man presented to the Ear, Nose and Throat (ENT) clinic with right-sided otalgia, discharge and non-healing ulcer on the outer ear canal for a couple of months. His medical history includes diabetes and chronic obstructive pulmonary disease. On examination, he had a subcentimetre ulcer in the right mid-ear canal. The rest of the ENT examination was normal.

Initial biopsy of the ear canal ulcer was nondiagnostic although atypical cells were noted. A repeat biopsy showed features compatible with basal cell carcinoma (BCC). CT and MRI scans of the neck showed $2 \mathrm{~cm}$ soft tissue mass in the right ear canal extending to the adjacent parotid gland (figure 1). The patient had limited lateral petrosectomy and superficial parotidectomy to achieve primary clearance. Postoperative histology showed ceruminous adenocarcinoma (CA) with positive margins. A further resection was planned, but unfortunately, the patient died from causes unrelated to the primary ear lesion.

Ceruminous glands are modified apocrine adnexal glands of the external auditory canal (EAC) and rarely gives rise to malignant changes. There are few natural barriers in the EAC; malignant tumours can spread into the parotid gland and surrounding lymphatics or to the temporal bone. CA poses a challenge to pathologists as this is a rare tumour, with one large centre reporting only $0.00025 \%$ of all the surgical specimens, and 2.4\%-5\% of all ear canal malignancies. ${ }^{12}$ Histologically, the lesion was a highly infiltrative basaloid tumour with cribiform, tubular and cord-like infiltrative patterns with perineural invasion (figure $2 \mathrm{~A}-\mathrm{C}$ ). It was neither originating from the epidermis of the ear canal nor from the parotid. The morphology was that of an adenoid cystic carcinoma, and with origin from the ear canal, it was compatible with a CA, adenoid cystic carcinoma subtype.

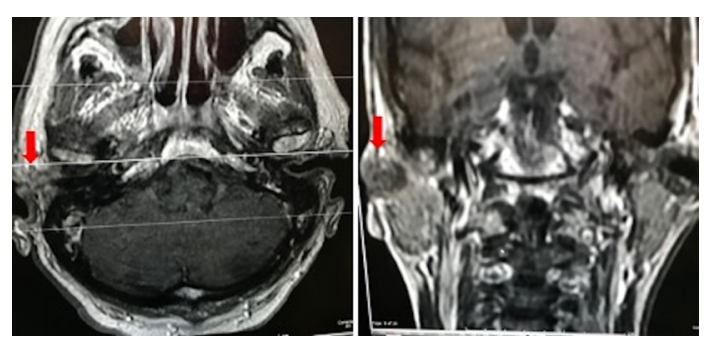

Figure 1 Axial and coronal views of MRI neck showing $2.0 \times \mathrm{cm} 1.6 \mathrm{~cm}$ soft tissue mass (red arrow) beneath the right ear canal extending to the adjacent parotid gland.

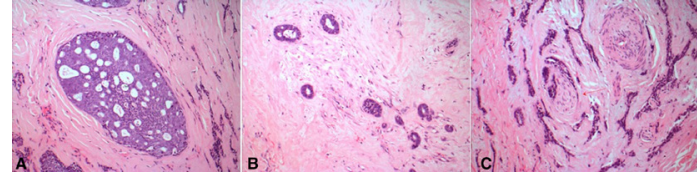

Figure 2 Histology of specimen showing highly infiltrative basaloid tumour with (A) cribiform, (B) tubular and $(C)$ cord-like infiltrative pattern with perineural invasion (red arrow) compatible with ceruminous adenocarcinoma (H\&E, original magnification $\times 200$ ).

The initial punch biopsy was reported as a BCC; the diagnosis was revised following examination of the larger excision specimen. This highlights the potential pitfall of a small biopsy of a rare tumour, CA, which partly resembles a much more common tumour BCC. However, histopathological analysis includes both incisional and excisional specimens and a diagnosis can occasionally change with assessment of more tumour material.

CA has non-specific symptoms including otalgia, discharge, ear fullness, vertigo, tinnitus, hearing loss, ear bleeding, ear canal polyp and facial palsy, which could initially suggest a simple benign inflammatory condition. ${ }^{3}{ }^{4}$ Considering this patient is diabetic with disproportionate otalgia, necrotising otitis externa was initially entertained. CA can present as prolonged subclinical phase lasting for years, with mean duration of symptoms in literature at 51.6 months. ${ }^{15}$ It has been reported to spread to lungs, bone, liver and kidneys, but less on neck nodes.

The primary treatment of CA is combined surgery and postoperative radiation. ${ }^{4}$ Primary surgical clearance poses technical difficulties and could include wide en bloc excision, parotidectomy and neck dissection. Perineural invasion is common and recurrence is as high as $90 \%$ if parotid gland was initially involved. ${ }^{1}$ Even with negative margins following resection, recurrence and distance

\section{Learning points}

- A wax-producing gland in the ear canal can give rise to a neoplastic process, which can be benign or malignant.

- Ceruminous adenocarcinoma (CA) is rare and can pose a diagnostic challenge to pathologists in small biopsies.

- The symptoms of CA are very non-specific and are similar to benign inflammatory lesions; it has a prolonged subclinical phase for years. 
metastasis occur. ${ }^{6}$ On average, patients with CA had a mean time from initial presentation to death of 4.7 years. ${ }^{1}$

Acknowledgements Many thanks to Ms Abi Thomas and Ms Katrina Hall who provided the full journals used in this report and to consultant radiologist Dr G Jurgen Brand for reviewing the scans.

Contributors EA and VP conceived the idea. EA and SN wrote the manuscript; LP and VP gave critical suggestions on the manuscript. EA, SN, LP and VP supported the final version.

Funding The authors have not declared a specific grant for this research from any funding agency in the public, commercial or not-for-profit sectors.

Competing interests None declared.

Patient consent for publication Obtained.

Provenance and peer review Not commissioned; externally peer-reviewed.

\section{ORCID iD}

Edgardo Abelardo http://orcid.org/0000-0002-6268-2882

\section{REFERENCES}

1 Crain N, Nelson BL, Barnes EL, et al. Ceruminous gland carcinomas: a clinicopathologic and immunophenotypic study of 17 cases. Head Neck Pathol 2009;3:1-17.

2 Jiang $X$, Jia L, Zhang X, et al. Clinical experience of 23 cases of adenoid cystic carcinoma of the external auditory canal. Oncol Lett 2020;20:144.

3 labal A, Newman P. Ceruminous gland neoplasia. Br J Plast Surg 1998:51:317-20.

4 Nagarajan P. Ceruminous neoplasms of the ear. Head Neck Pathol 2018;12:350-61.

5 Soon SL, Bullock M, Prince ME. Ceruminous adenocarcinoma: a rare tumour of the external auditory canal. J Otolaryngol 2001;30:372-7.

6 Jan J-C, Wang C-P, Kwan P-C, et al. Ceruminous adenocarcinoma with extensive parotid, cervical, and distant metastases: case report and review of literature. Arch Otolaryngol Head Neck Surg 2008;134:663-6.

Copyright 2021 BMJ Publishing Group. All rights reserved. For permission to reuse any of this content visit

https://www.bmj.com/company/products-services/rights-and-licensing/permissions/

BMJ Case Report Fellows may re-use this article for personal use and teaching without any further permission.

Become a Fellow of BMJ Case Reports today and you can:

- Submit as many cases as you like

- Enjoy fast sympathetic peer review and rapid publication of accepted articles

- Access all the published articles

Re-use any of the published material for personal use and teaching without further permission

\section{Customer Service}

If you have any further queries about your subscription, please contact our customer services team on +44 (0) 2071111105 or via email at support@bmj.com.

Visit casereports.bmj.com for more articles like this and to become a Fellow 